\title{
Parenting and Fundamental Movement Skills
}

\author{
Eka Fitri Novita Sari ${ }^{1}$ \\ ${ }^{1}$ Faculty of Sports Science, Universitas Negeri Jakarta, Indonesia \\ Correspondence: Eka Fitri Novita Sari, Faculty of Sports Science, Universitas Negeri Jakarta, Kampus B, Jl. \\ Pemuda 10, Rawamangun, Jakarta 13220, Indonesia. E-mail: efnovita@unj.ac.id
}

\author{
Received: January 16, 2014 Accepted: February 20, 2014 Online Published: February 28, 2014 \\ doi:10.5539/ass.v10n5p22 URL: http://dx.doi.org/10.5539/ass.v10n5p22
}

\begin{abstract}
This study aimed to determine differences between permissive and authoritarian parenting in play activities motion against the fundamental movement skills on second grade of elementary school students. This study used ex-post facto method that collects data through questionnaires and tests the appearance of motion. In order to collect data related to parenting types, indicators consisting three levels of scale using a range of up to three were used to measure the shape of the patterns of parenting in motion play activities at home. Test battery consisting of tests run, jump, kick, catch, throw, balance and, flexibility was used to measure the fundamental movement skills. The research was carried out in 5 villages at Rawamangun Elementary School in East Jakarta. The population consists of 183 students however 36 students were selected. The analysis found that there were significant differences in fundamental movement skills of second grade elementary school students between permissive parenting and authoritarian parenting. The results show that the fundamental movement skills of permissive parenting are better than the fundamental movement skills of authoritarian parenting.
\end{abstract}

Keywords: parenting, fundamental movement skills

\section{Introduction}

Family is the most important thing in the lives of children. Family is the first place to determine the choice of movement for children. It influences on the attitudes and behavior of the movement of a child. Family gives first major influence to the development of a child's movement. (Payne \& Isaacs, 1995).

Fundamental movement skills is a series of movements that has been the basis of a child's movement in a variety of activities in sports, games, dance and social environment of children. Through basic movement skills, a child will be able to show the ability of motion and gain more benefits. In addition to the healthy condition of the body, the child will develop confidence and become independent. Mastery of basic movement skills will help children to be more confident in doing all the activities because they knew the ability of motion. Children who master basic movement skills also have positive social skills. They love to play with their friends because it can compensate for motion peers such as jumping, running and other play activities since children are basically active and likes to play around.

Play activities at home is a series of activities that children do in order to develop basic motor skills because it stimulates children's movement potential. The importance of play activities for the development of basic movement skills currently continues to be considered a fading trend, especially in big cities like Jakarta. Many background factors drive these conditions, addressing the misconceptions among parents about motion activities that children do through play activities, as it affects the culture or habit of the child's movement. Many parents restrict or even prohibit their children from playing. Besides the time and opportunities, parents rarely accompany their children in playing activities; hence it is one of the problems in developing children's fundamental movement skills.

Motion education should be practiced at home because parents have the duty and responsibility of educating a child's development. How parents apply education to children in a family reflects how the application of parenting types in the family. Parenting is a model of treatment or action of parents in guiding and nurturing young children to provide for themselves. Parenting can also be defined as all actions and treatment into their child's. It differs from one parent to another and from one child to another. In this study, permissive and authoritarian parenting types were examined. Both patterns will provide its own influence on children's play options that will ultimately affect their fundamental motor development. In addition, parents misunderstand 
parenting behaviour by restricting and prohibiting their children from playing, and the lack of time and opportunity for the parents to guide and direct the play activity make the selection of authoritarian and permissive parents as accurate. This research was conducted with the hope of informing whether the application of permissive parenting and authoritarian parent will affect the child's basic movement skills. The results obtained will make important information to parents in dealing with parenting application to the motion of the child's activity.

\section{Discussion}

\subsection{Fundamental Movement Skills}

Fundamental movement skills are important for a child's basic motor development (Teo-Koh Sock Miang, 2010). Supandi (1983) defines the basic movement skills as movement patterns that form the basis for more complex movement dexterity while David Gallahue (2002) states that the overall movement skills is a term of three categories of locomotor movements, manipulation and stability. Dauer and Pangrazi (1975) states that the basic skills can be divided into three categories, each of which provides an explanation consideration separately. It allows a child to show the differences in the selection of abilities in each category.

Thus, it can be said that the fundamental movement skills is a series of appearances of a child's complex motion, clearly and real when he was capable of performing motion in sports activities and other physical activities, that consists of several components such as motion locomotor, non-locomotor and manipulation.

David Gallahue (2002) divides fundamental movement skills into three activities such as running and jumping, manipulative activities such as throwing and catching, and stabilizing and balancing activities such as walking on the bridge. Pangrazi and Dauer (1992) discuss further and divide the motion into three fundamental movement categories, namely locomotor skills, non-locomotor skills, and manipulative skills. (1) Locomotor skills refer to movement that uses the body to move from one place to another or lift the body up like jumping and hopping. Other examples include walking, running, skipping, running like leaping, slidingand galloping, (2) Non-Locomotor skills are defined as a form of motion without transferring from one place to another. This category includes movement: bending, stretching, pushing, and pulling, twisting, turning, and shaking, (3) Manipulative skills are categorized as a movement in a game when a kid id holding some kind of object or tool. Most of these capabilities involve the hands and feet, but other parts of the body can also be used. Most manipulative things are fundamental for a lot of skills in games like throwing, catching, and kicking.

Rusli Lutan (2001) explains as follows: (1) Locomotor movement is every movement that is performed when the body is moved towards horizontal, or vertical, from one point to another in a space. Locomotor movements include running, jumping and landing and hopping, skipping, and jump as high as possible, or as far as possible with a single leg. (2) Manipulative movement is a motion that involves large muscles in a physical activity that involves (a). giving the power to an object directly, and (b). efforts to receive power from an object, such as throwing the first instance and second instance catch. However, the deployment was not just by hands, but also with the foot. Kicking a ball is also an example of manipulative movement, (3) The stability is where the body settles in one position but moves on to the horizontal or vertical axis. Static balance is also quite basic types of motion. In such condition, a child tries to maintain balance in order to keep his weight from falling into the pivot field. Stability motion includes axial movement such as reaching, stretching, bending play, stalling, lifting, pushing and pulling.

Based on the definitions and explanations, it can be concluded that the fundamental movement skills is a pattern of behavior that is expressed through three motion activities that have different characteristics and it is related to (1) moving motion (locomotor): running, jumping, (2) unmoving motion (non-locomotor): balance, flexibility, and (3) manipulative motion: throwing, catching, kicking.

\subsection{Parenting}

Suyoto (1996) said parenting refers to the ways parents apply reciprocally in dealing with their children to establish attitudes and behavior as expected of parents and the community with the aim to become mature in time. Gallahue and Ozmun (2002) state that the effect of treatment on the parents during infancy and early age can affect the development and status of the children themselves because the involvement of children in this age is strongly influenced by parental care. Hurlock (2005) argues that parenting is related to how the family provides huge impact for the development of a child. Maurice (2004) states that parenting is not only about caring for or supervising children, but parenting also includes: education, manners, discipline, responsibility, knowledge and relationships which are rooted in the parents' knowledge.

Syamsu Yusuf (2000), states that the parents in the family have more function, such as: (1). as a guardian for 
children and other family members, (2). as a resource needs, both physical and psychological, (3). as an appropriate model behavior patterns for children to learn to be a good member of the community, (4). as an appropriate mentor for the development of social behavior, (5). as a mentor in learning motor skills, verbal and social needs to be adapted, (6). Stimulator for the development of children's ability to achieve, both in school and society.

Based on the statement above, it can be concluded that parenting is the attitude or actions of parents perform, or apply, to children through interaction either verbal or non-verbal on various aspects of child development.

\subsection{Permissive Parenting}

Permissive parenting refers to parents who let children do as they please, with a few boundaries. This creates "child-centeredness" in the family group. It encourages children to be smart, independent and adaptable to the society. Moreover, permissive parenting also promotes self-confidence, creativity and being mature (Hurlock, 2005). Permissive parenting is a type of parenting pattern that frees the child to determine his preferred choice. Usually it occurs among parents who are too busy with work and other affairs.

Desmita (2009) differentiates permissive parenting into in two forms i.e. permissive-indulgent and permissive-indifferent. One hand, permissive-indulgent is a parenting style practiced by parents who are very involved in the child's life, but set a few boundaries or control over them. Still, parents tend to let their children do whatever they want. Permissive-indifferent, on the other hand, is a parenting style where parents are not involved in the child's life.

Based on the above statement, it can be concluded that the patterns of permissive parenting are: (1). giving freedom to children to express a desire / impulse, (2). have acceptance. (3). have low control, (4). limited critics, (5). less rules, (6). lack of demand, (7). rarely impose penalties, (8). Be cool or not emotional, (9). Do not care to anyone, (10). allowing person.

\subsection{Authoritarian Parenting}

Desmita's (2009) patterns of authoritarian parenting is a style of parenting that limits and requires children to follow the commands of parents. Parents give strict limits and do not provide a great opportunity for children to express their opinions. Children of authoritarian parents tend to be suspicious of others and of themselves too, feeling awkward in touch with peers, tend to be difficult to adjust to at the beginning of school and have lower academic achievement compared with other children.

According to Siti Hartinah (2008) in "Education of authoritarian", authoritarian parenting is where children always have to follow what has been laid down by their parents. Authoritarian parenting was coercive, harsh and stiff where parents will make the rules that must be obeyed by their children. Parents will be emotional and angry when children do things that are not in accordance with the ways or rules desired by parents. Mental and physical punishment will often be accepted by the children on the grounds that the child continues to remain obedient and disciplined and respect the parents who had raised him. But behind that, it is usually the authoritarian parents' upbringing that could lead them to be more disciplined and more responsible in life.

Based on the above statement, it can be concluded that authoritarian parenting: (1). educates children to obey the will of the parents, (2). tightly supervises, (3). demands higher, (4). limiting, (5). often criticizing, (6). physically punishing, (7). cares less about the will of the child, (8). commanding, (9). setting up, (10). do not understand the rights of the child, (11). often threatening, (12). hostile, (13). emotional, (14). rejecting.

\section{Research Methodology}

This research used ex-post facto method, by collecting data through questionnaire and test motion performance. To collect data related to parenting questionnaire, indicators that measure how the shape parenting to play in motion activities at home were prepared/developed. Test battery such as run, jump, kick, catch, throw, balancing and flexibility was used to test the fundamental movement skills .

Before determining the selected samples, population was first established in accordance with the purpose of research. The selected population characteristics are as follows:

a. The population consists of students of Second grade of Elementary School located in the village Rawamangun, of which the physical education teacher's academic background is sports science in education.

b. A total of 183 Second grade of Elementary School students from 5 (five) elementary schools located in the village Rawamangun who suit the criteria qualified as the samples .

The sampling measure was conducted as follows: Samples were collected by using Total Sampling i.e. 183 
students. The questionnaires classified students into two groups namely (1). Students with permissive parenting, (2). Students with authoritarian parenting. 36 students were selected for the study.

\section{Results}

\subsection{Data of Fundamental Movement Skills of Students with Permissive Parenting (A1)}

The overall data of fundamental movement skills of students with permissive parenting reveal 18 students with the highest score of 60.45 and the lowest score of 44.22, an average score of 51.97, standard deviation 4.30, modus 52.8 and median 57.7. Frequency distribution can be seen in the following table:

Table 1. Frequency distribution of fundamental movements skills of students with permissive parenting

\begin{tabular}{cccc}
\hline No. & Interval Class & Absolute Frequency & Relative Frequency \\
\hline 1 & $44,22-47,46$ & 3 & 0,167 \\
2 & $47,47-50,70$ & 5 & 0,278 \\
3 & $50,71-53,95$ & 3 & 0,167 \\
4 & $53,96-57,19$ & 5 & 0,278 \\
5 & $57,20-60,45$ & 2 & 0,111 \\
& & $\mathbf{1 8}$ & $\mathbf{1}$ \\
\hline
\end{tabular}

\subsection{Data of Fundamental Movement Skills of Students with Authoritarian Parenting (A2)}

The overall data of fundamental movement skills of students with authoritarian parenting show 18 students with the highest score of 56.49 and the lowest score of 39.5 , an average score of 48.42 , standard deviation 4.79 , modus 45.09 and median 50.19. Frequency distribution can be seen in the following table:

Table 2. Frequency distribution of fundamental movement skills of students with authoritarian parenting

\begin{tabular}{cccc}
\hline No. & Interval Class & Absolute Frequency & Relative Frequency \\
\hline 1 & $39,5-42,89$ & 2 & 0,111 \\
2 & $42,90-46,28$ & 6 & 0.333 \\
3 & $46,29-49,68$ & 2 & 0.111 \\
4 & $49,69-53,08$ & 4 & 0.222 \\
5 & $53,09-56,49$ & 4 & 0.222 \\
& & $\mathbf{1 8}$ & $\mathbf{1}$ \\
\hline
\end{tabular}

\subsection{The Differences between the Fundamental Movement Skills of Permissive and Authoritarian Parenting}

Results of fundamental movement skills of the students with permissive parenting showed an average value of 51.97 with a standard deviation of 4.30 , while the fundamental movement skills of the students with authoritarian parenting showed an average value of 48.42 with a standard deviation of 4.79 .

Results of analysis of variance (ANOVA) related to the differences in fundamental movement skills of students with permissive parenting with fundamental movement skills of students with authoritarian parenting as a whole can be seen in the following table. 
Table 3. Summary of ANOVA score calculation of fundamental movement students at $\alpha=0.05$.

\begin{tabular}{cccccc}
\hline Varians Sources & $\mathrm{Db}$ & $\mathrm{JK}$ & $\mathrm{RK}=\mathrm{JK} / \mathrm{db}$ & $\mathrm{Fh}=\mathrm{RK} / \mathrm{RDK}$ & $\mathrm{Ft}$ \\
\hline In row (b) & $\mathrm{b}-1=1$ & 118.1207 & 118.1207 & 7.1439 & 4.15 \\
Incolumn (k) & $\mathrm{k}-1=1$ & 195.4870 & 195.4870 & 11.8230 & 4.15 \\
Interaction (bxk) & $1 \mathrm{x} 1$ & 313.9421 & 313.9421 & 18.9871 & 4.15 \\
Depth & 32 & 529.1047 & 16.5345 & --- & --- \\
Total Correction & 35 & 843.0469 & & --- & --- \\
\hline
\end{tabular}

Results of analysis of variance (ANOVA) were obtained as shown in the table above, shows that the value calculated for $\mathrm{F}$ is $7.14 \alpha=0.05$ level. This means that the null hypothesis is rejected. By rejecting the null hypothesis, this means the alternative hypothesis is accepted. Thus, it means that there are significant differences between the fundamental movement skills of students with permissive parenting with fundamental movement skills of students with authoritarian parenting. Then the study of alternative hypothesis which states that the fundamental motor skills of students with permissive parenting are better than the fundamental movement skills of students with authoritarian parenting was received.

\section{Discussion and Analysis of Results}

The results of the analysis found out that there are differences in the fundamental movement skills of students from the two groups. Groups of students with permissive parenting obtained an average value of 51.97 which is greater than the students who received the authoritarian parenting which is 48.42 . Tukey test results also test the first hypothesis with $\mathrm{Q}_{\text {count }}$ acquisition of 6.88 is greater than the $\mathrm{Q}_{\mathrm{tab}}$, of 3.00 at $\alpha=0.05$.

The calculation results showed that overall score of fundamental movement skills of students from permissive parenting are better than the score of fundamental movement skills of students from authoritarian parenting. It also confirms that there are significant differences between the scores of fundamental movement skills of students with permissive and authoritarian parenting; therefore, different parenting pattern contributes to different score.

\section{Conclusions and Recommendations}

Based on the data obtained, the hypothesis testing results and discussion of the results of this study, it can be concluded that there were significant differences in fundamental movement skills at second grade elementary school students between permissive and authoritarian parenting. The calculation results showed that overall score of fundamental movement skills of students with permissive parenting better than the score of fundamental movement skills of students with authoritarian parenting. It also confirms that there are significant differences between the scores of fundamental movement skills of students with permissive and authoritarian parenting suggesting that different parenting type results in different score.

1) Parents should allow time for the child to perform a variety of playing activities because the motion activities that children do have an important thing in stimulating the development of a child's basic motion.

2) Limited time or opportunity for parents to accompany the child to play does not make an excuse for parents to restrict children to play because the restrictions will affect a child's basic motor development.

3) The scope of this research is still limited and the population of students with limited sample, thus generalization can only be done on the population. It is suggested that further research should examine a bigger sample in a different area to get better result.

4) Other researchers can search for and examine other variables that can affect the fundamental movement skills of elementary school students.

\section{References}

Anon. Pengembangan Gerak Dasar Peserta Didik Kelas 1 dan 2 Sekolah Dasar (Usia 6-8 tahun), Jakarta: Departemen Pendidikan Nasional Pusat pengembangan Kualitas Jasmani, 2004.

Cholik, M. T., \& Lutan, R. (1996/1997). Pendidikan Jasmani dan Kesehatan. Jakarta: Direktorat Jenderal Pendidikan Tinggi Departemen Pendidikan dan Kebudayaan.

Dauer, V. P., \& Pangrazi, R. P. (1975). Dynamic Physical Education for Elementary School Childrens (5th ed.). USA: Burgess Publishing Company, Minneapolis, Minnesota. 
Desmita, Psikologi Perkembangan, Bandung: PT Remaja Rosdakarya, 2009.

Gallahu, D. L., \& Ozmun, J. B. (2002). Understanding Motor Development Infants, Children, Adolescents, Adults. New York: McGraw-Hill.

Hartinah, S. (2008). Perkembangan Peserta Didik. Bandung: PT Refika Aditama.

Hurlock, E. B. (2005). Perkembangan Anak Jilid 2 Edisi Keenam. Jakarta: Penerbit Erlangga.

Lutan, R. (2001). Asas-asas Pendidikan Jasmani, Pendekatan Pendidikan Gerak di Sekolah Dasar. Jakarta: Dirjen Olahraga.

Matakupan, J. (1995). Teori Bermain: Modul 1-6. Jakarta: Depdikbud.

Maurice et al. (2004). Cara-cara Efektif Mengasuh Anak dengan EQ. Jakarta: Erosco.

Miang, T. K. S. (2010). Fundamental Movement Skills for Growing Active Learners. Singapore: The Singapore Sports Council.

Pangrazi, R. P., \& Dauer, V. P. (1992). Dynamic Physical Education for Elementary School Childrens Tenth Edition. New York: MacMillan.

Rusli Lutan, Belajar Keterampilan Motorik, Pengantar Teori dan Metode, Jakarta, DIRJEN DIKTI, 1988.

Siedentop, D. (1994). Introduction to Physical Education, Fitness and Sport, Mountain View. California: Mayfield Publising Company.

\section{Copyrights}

Copyright for this article is retained by the author(s), with first publication rights granted to the journal.

This is an open-access article distributed under the terms and conditions of the Creative Commons Attribution license (http://creativecommons.org/licenses/by/3.0/). 